\title{
UKRAINIAN POLICY ON INCREASING INTERNAL GAS PRODUCTION
}

\section{Ihor Moshenets ${ }^{1}$}

DOI: https://doi.org/10.30525/978-9934-26-076-6-33

The purpose of our analysis is to explain how Ukraine tried to limit its dependency on Russian gas import in post-2014 period by the increasing of its internal gas production.

Ukraine possesses more than one trillion cubic meters of proven gas reserves [15]. The golden age of Ukrainian internal gas production was in the 70 s under the time of the Soviet Union when the yearly extracted amount of gas accounted for nearly 68,5 billion cubic meters (bcm). However, since that time it has regularly declined. As of 2015, the whole national production accounted for only 19,9 bcm [5, p. 240].

In order to attract more private investments to the gas industry, the Ukrainian parliament committed a lot of measures. It decreased the royalty rates for developing new gas wells. Another law was passed in order to simplify the procedures of getting the loan land with potential gas wells. However, this bill registered in the parliament in 2015 and passed only in 2018 perfectly illustrated the problem of low speed in implementing needed

\footnotetext{
${ }^{1}$ National Institute of Strategic Studies, Ukraine
} 
decisions. The deregulation was also accompanied by demands for a higher level of transparency - MPs voted for the bill which introduced demands of EITI (Extract Industries Transparency Initiative) into Ukrainian law. The standards of State Service of Geology and Subsoil's were also improved [12].

Nevertheless, these changes were not sufficient for attracting to Ukraine world-class investors. At the beginning of 2019 Volodymyr Groysman's government announced the tender for the conclusion of the production-sharing agreement with interested parties on 12 prospective gas fields. The biggest international energy companies, which earlier showed some interest in Ukrainian markets, skipped the competition. Only two foreign companies, Vermilion Energy and Aspect Energy, took part in the process by submitting applications in partnership with state-owned company Ukrgazvydobuvannia. However, later they announced their exit from the project. Therefore, most participants were the subsidiaries of Ukrainian energy companies, created specifically to take part in production-sharing agreement processes [6]. The final versions of the agreements were signed up only in December 2020 and only in regard to seven gas fields out of nine [13].

A similar story with the inability to find investors with worldwide business reputations was with gas field Dolphin. It is located near Odesa and is one of the biggest potential sources of natural gas on the bottom of the Black Sea. The tender for its elaboration was held in July August 2019 and was won by company Trident Black Sea. However, Prime Minister Groysman expressed disappointment with the results of the tender because Ukraine failed to attract some major world-class investors [3]. Therefore the results were cancelled. Later Denys Shmygal's government gave the allowance for gas extraction on the territory of Dolphin gas field to national monopolist Naftogaz without any tender [4].

The basic policy plan of the Ukrainian government was to increase internal gas production from $20 \mathrm{bcm}$ in 2015 to $27,6 \mathrm{bcm}$ in 2020 [1, p. 9-10]. The main role here was dedicated to state-owned company Ukrgasvydobuvannia (UGV) which is the subsidiary of national energy holding Naftogaz. This company as the biggest gas producer in the country was expected to increase its production to $20 \mathrm{bcm}$ in 2020 (so-called program «20-20»). However, this task was not achieved. Despite UGV increased its production from $14.5 \mathrm{bcm}$ in 2015 to $15.5 \mathrm{bcm}$ in 2017 (the company's annual record), since 2018 its extraction started to fall and decreased to $14.9 \mathrm{bcm}$ in 2019 [7]. In 2020 the whole gas production of Naftogaz Group accounted for 13.45 bcm [8].

We could define three basic reasons for this failure. The first one were the bureaucratic hurdles with getting permits for research and development of gas deposits from local regional councils or unreformed rigid State Service of 
Geology and Subsoil. Also, many of the permits were given for nonperforming projects to companies or private people who did not plan immediately to develop new gas wells but made it as a reservation for the distant future. In December 2019 Prime Minister Olexiy Honcharuk said that a third of all projects, which accounted for nearly 80, was inactive [11]. Only in March 2021 President Volodymyr Zelenskiy gave the task in the framework of his duties as a Head of National Security and Defense Countries to organize massive revision of all licenses given for gas production and to cancel some of them [10].

The second hypothetical reason was the possible lack of expert justification of the possibility to reach particular levels of gas production for a given time. The «20-20 program» was opposed by the National Trade Union of Geologist and Geology Professors from the National Academy of Sciences. They criticized heavily the whole vision of the plan for concentrating on exploration of offshore gas reserves instead of onshore; for not using all possible ways of maximizing output on existing gas fields (horizontal drilling); for contracting foreign equipment instead of produced by local companies for less price [14].

The third reason is the preservation of corruption and rent-seeking motivation in relation to Ukraine's natural resources. For example, in media circulated information about such suspicious cases like «Arcona affair». Poltava regional council was blocking their permissions for UGV of one rich gas field and then gave it to an unknown private company founded by a person having common business interests with the highest political officials [9].

A similar conspicuous situation was with the Yusivka gas field. Royal Dutch Shell was developing its 10-billion shale gas project in Donbas basin's Yusivka gas field since 2012. But in 2015, due to geographical closeness to the area of military actions company, exited the Ukrainian market [5, p. 219]. These already prepared for elaboration wells with technical equipment were given by the Ukrainian government to the little-known company without proper tender. It created suspicion about possible corruption in that decision. In 2020 Yusivka gas field was transferred to Naftogaz [2].

To conclude, Ukrainian gas production was not increased enough to eliminate completely its dependence on import supplies. Despite some objective economic hurdles connected to the situation on the world markets, the main reasons for that policy result were inefficient functioning of Ukrainian state institutions and limited political will of political elites to perform radical changes. Nevertheless, Ukraine has substantially improved its regulatory base which gives hopes that in the future it may become fully independent in this important area of the economy. 


\section{References:}

1. Bayramov A., Marusyk Y. (2019) Ukraine's unfinished natural gas and electricity reforms: One step forward, two steps back. Eurasian Geography and Economics, no. 60(1), pp. 73-96. DOI: https://doi.org/10.1080/15387216.2019. 1593210

2. Bryl R. (2020) Kabmin rozporjadyvsja prodaty Naftoghazu naftoghazove rodovyshhe Juzivsjke. Liga Novosti. Available at: https:/ua-news.liga.net/economics/ news/kabmin-rozporyadivsya-prodati-naftogazu-naftogazove-rodovische-yuzivske

3. Ekonomichna Pravda (2020) Ghrojsman khoche inicijuvaty novyj konkurs po «Deljfinu». Ekonomichna Pravda. Available at: https://www.epravda.com.ua/news/ 2019/07/28/650052/

4. Ekonomichna Pravda (2021) «Naftoghaz» otrymav specdozvoly na rozrobku diljanky «Deljfin» na 30 rokiv. Ekonomichna Pravda. Available at: https://www.epravda.com.ua/news/2021/01/11/669849/

5. Grigas A. (2017) The New Geopolitics of Natural Gas. Harward University Press.

6. Jerjomenko A., Kobal H. (2019) Chy varto Ukrajini chekaty investycij u ghazovydobutok? Dzerkalo Tyzhnya. Available at: https://zn.ua/ukr/energy_market/ chi-varto-ukrayini-chekati-investiciy-u-gazovidobutok-327378_.html

7. NAK Naftogaz (n.d.). Gas production. Naftogaz. Available at: https://www.naftogaz.com/www/3/nakweben.nsf/0/2F6A8DAFC83F1A49C2257F9B0 024168B?OpenDocument\&Expand=1.1\&

8. Naftogaz Ukrgazvydobuvannia (2021) Naftogaz stabilizes production: 2020 performance exceeds the target. Naftogaz Ukrgazvydobuvannia. Available at: https://ugv.com.ua/en/page/naftogaz-stabilizue-vidobutok-rezultat-2020-go-roku-vise-planu

9. Nashi Groshi (2018) Osnovnym vlasnykom ghazovoji «Arkony» stav eksdyrektor «5 elementu» Poroshenka-Kononenka (dodano). Nashi Groshi. Available at: https://nashigroshi.org/2018/11/15/osnovnym-vlasnykom-hazovoi-arkony-stav-eksdyrektor-5-elementu-poroshenka-kononenka/

10. National Security and Defense Council of Ukraine (2021) Prezydent proviv zasidannja RNBO, na jakomu buly zastosovani sankciji proty kolyshnjogho Prezydenta Janukovycha, inshykh vysokoposadovciv ta nyzky kompanij u sferi nadrokorystuvannja. National Security and Defense Council of Ukraine. Available at: https://www.rnbo.gov.ua/ua/Diialnist/4849.html

11. Novoe Vremya Biznes (2019) V Ukrajini cherez korupciju ne pracjuje kozhen tretij dozvil na vydobutok nafty i ghazu - Ghoncharuk. Novoe Vremya Biznes. Available at: https://biz.nv.ua/ukr/markets/v-ukrajini-cherez-korupciyu-ne-pracyuyekozhen-tretiy-dozvil-na-vidobutok-nafti-i-gazu-goncharuk-50057657.html

12. The Ministry of Energy and Coal Industry of Ukraine (2019) Khid reform u naftoghazovydobuvnij ghaluzi Ukrajiny. The Ministry of Energy and Coal Industry of Ukraine. Available at: http://mpe.kmu.gov.ua/minugol/control/uk/publish/printable_ article?art_id $=245415392$

13. The Ministry of Energy and Coal Industry of Ukraine (2020) Pidpysano ughody pro rozpodil produkciji na semy naftoghazovykh diljankakh. The Ministry of 
Energy and Coal Industry of Ukraine. Available at: http://mpe.kmu.gov.ua/ minugol/control/publish/article?art_id=245504587

14. Vdovychenko A., Yermakov P., Stovba S. (2020) Shho pereshkodzhaje rozvytku ghazovydobutku v Ukrajini. Dzerkalo Tyzhnia. Available at: https://zn.ua/ukr/energy_market/scho-pereshkodzhaye-rozvitku-gazovidobutku-vukrayini-350924_.html

15. Worldometer (n.d.). Ukraine Natural Gas. Worldometer. Available at: https://www.worldometers.info/gas/ukraine-natural-gas/ 